\title{
EDITORIAL CHEST PAIN IN WOMEN. IS IT ALWAYS ATHEROSCLEROTIC?
}

\author{
Tariq Ashraf ${ }^{1}$, Feroz Memon² \\ ${ }^{1}$ Karachi Institute of Heart Diseases, Karachi, Pakistan, ${ }^{2}$ Isra University Hospital, Hyderabad, Pakistan
}

Patients both male and female with diagnosis of Acute Coronary Syndrome (ACS) present with chest pain as presenting complaint. Lichtman $\mathrm{JH}$ et al. in his study with ACS showed that $93 \%$ of women presented with chest pain or discomfort. ${ }^{1}$ As compared to men women experience more associated symptoms as primary complaint. The associated symptoms are fatigue, dyspnea, backache, flue like symptoms, indigestion, palpitations and most common is anxiety \& feeling scarry. ${ }^{2}$ Keeping these scenarios in mind one should inquire this associated presentation along with chest pain or discomfort in evaluating ACS in women.

In continuation with symptoms there is quite a debate on pathophysiology of Acute Myocardial infraction in men and women regarding coronary pathologic features. ${ }^{3}$ Type 1 plaque rupture most common in both genders with plaque erosion most common in women in non-obstructive coronary artery disease. ${ }^{4}$ Spontaneous coronary artery dissection (SCAD) having high mortality exists in the absence of risk factor of ACS. ${ }^{5}$

It was found in women up to $35 \%$ of patients with mean age of 42 to 53 years with a MACE (Major acute coronary event) of $47.4 \%$ and 10 years mortality rate of $7.7 \%^{2}$ SCAD seen in peripartum cases, oral contraception use, lack of exercise, connective tissue disorders and vasculidites. It is important for the physician to have in mind these disorders to avoid complications of coronary interventions.

In a scientific statement from AHA, Mehte LS et al. showed a lower prevalence of atheroscrotic CAD in women. ${ }^{3}$ These are certain scoring system, ${ }^{6}$ that under present women because of vague symptoms and presentation. These scoring systems lead to decrease hospital admission and less noninvasive cardiac testing. For risk satisfaction of chest pain female gender should not be taken as sole criteria for presence or absence of coronary events in presence of other multiple factors.

The last but not the least is the psychosocial stress more in women than in men. It has been found that young women who present with early onset myocardial infarction have more psychosocial risk factors in comparison to men of similar age ${ }^{3}$ probably having high rates of poverty and trauma exposure during childhood because of various reasons. ${ }^{7}$ Different studies are endorsing relationship between depression and ischemic heart disease as prognostic factor after ACS. ${ }^{7}$ In our population where there is lack of education, poverty, awareness of disease especially in women the physician should ponder on different factors mentioned above i.e. presentation perceptions, prevalence, pathophysiology and psychosocial stress for evaluation and management of chest pain.

\section{REFERENCES}

1. Lichtman JH, Leifheit-Limson EC, Watanabe E, Allen NB, Garavalia B, Garavalia LS, et al. Symptom recognition and healthcare experiences of young women with acute myocardial infarction. Circ Cardiovasc Qual Outcomes. 2015;8:S31-8.

2. Vargas K, Messman A, Levy PD. Nuances in Evaluation of Chest Pain in women. JACC Case Rep. 2021;3(17):1793-7.

3. Mehta LS, Beckie TM, DeVon HA, Grines CL, Krumholz $\mathrm{HM}$, Johnson MN, et al. Acute myocardial infarction in women: a scientific statement from the American Heart Association. Circulation. 2016;133:916-47.

4. Mukherjee D. Myocardial infarction with nonobstructive coronary arteries: a call for individualized treatment. J Am Heart Assoc. 2019;8(14):e013361.

5. Hayes SN, Kim ESH, Saw J, Adlam D, Arslanian-Engoren $\mathrm{C}$, Economy KE, et al. Spontaneous coronary artery dissection: current state of the science: a scientific statement from the American Heart Association. Circulation. 2018;137:e523-e557.

6. Preciado SM, Sharp AL, Sun BC, Baecker A, Wu YL, Lee MS, et al. Evaluating sex disparities in the emergency department management of patients with suspected acute coronary syndrome. Ann Emerg Med. 2021;77(4):41624.

7. Lichtman JH, Froelicher ES, Blumenthal JA, Carney RM, Doering LV, Frasure-Smith N, et al. Depression as a risk factor for poor prognosis among patients with acute coronary syndrome: systematic review and recommendations: a scientific statement from the American Heart Association. Circulation. 2014;129:135069.

\section{Address for Correspondence:}

Dr. Tariq Ashraf, Karachi Institute of Heart Diseases, Karachi, Pakistan

Email: tariqash45@gmail.com

Citation: Ashraf T, Memon F. Chest Pain in Women. Is it Always Atherosclerotic?. Pak Heart J. 2021;54(04):291. https://doi.org/10.47144/phj.v54i4.2239 